\title{
Propagation of Some Medicinal and Aromatic Plants in Turkey by Biotechnological Methods
}

\author{
Mehmet SEZGİN1, , Emine KAPDAN² \\ ${ }^{1}$ Department of Biology, Faculty of Science, Çankırı Karartekin University, Uluyazı Campus, Çankırı, Turkey \\ ${ }^{2}$ Graduate School of Natural and Applied Sciences, Çankır Karatekin University, Çankırı, Turkey \\ ORCID ID: Mehmet SEZGIN: https:/ / orcid.org/0000-0001-7053-0371; Emine KAPDAN: https:// orcid.org/0000-0003-4530-4860
}

\begin{abstract}
Received: 07.10 .2019
Accepted: 09.10.2019

Published online: 20.12.2019

Issue published: 20.12 .2019

Abstract: In this study, the reports covering the years 1984-2019 for propagation, reproduction, and breeding of Sideritis perfoliata L., S. stricta Boiss. \& Heldr., S. erythrantha Boiss. \& Heldr., Leucojum aestivum L., Borago officinalis L., Cuminum cyminum L., Lavandula angustifolia Mill., Rosa damascena Mill., R. canina L., Thymus longicaulis subsp. longicaulis C.pres 1., Tussilago farfara L., Digitalis lanata Ehrh., D. lamarckii Ivan., Crocus sativus L., Capsicum annuum L., Origanum syriacum subsp. bevanii (Holmes) Greuter \& Burdet, Ecballium elaterium (L.) A. Rich., Sinapis arvensis L., Papaver somniferum L., P. bracteatum Lindl., Capparis spinosa L., Coriandrum satioum L., Petroselinum crispum (Mill.) A. W. Hill., Silybum marianum (L.) Gaertn., Ziziphus jujuba Mill., Peganum harmala L., Carthamus tinctorius L., Rumex acetosella L., Dianthus caryophyllus L., Ocimum basilicum L., Mentha spicata subsp. spicata L. taxa, used for medicinal purposes in Turkey with biotechnological methods, have been reviewed. Biotechnological methods such as in vitro organogenesis and somatic embryogenesis can be used in plants for a sufficient amount of production and desired yield in medicinal and aromatic plants. Moreover, various breeding practices can be carried out by using biotechnological methods. In addition to the traditional methods of propagation in medicinal and aromatic plants, the provision of mass and clonal propagation via in vitro propagation techniques has a significant potential.
\end{abstract}

Keywords: Organogenesis, somatic embryogenesis, medicinal and aromatic plant.

\section{Türkiye'de Bazı Tıbbi ve Aromatik Bitkilerin Biyoteknolojik Yöntemlerle Çoğaltılma Çalışmaları}

Öz: Bu çalışmada, Türkiye'de tıbbi amaçlı olarak kullanılan Sideritis perfoliata L., S. stricta Boiss. \& Heldr., S. erythrantha Boiss. \& Heldr., Leucojum aestivum L., Borago officinalis L., Cuminum cyminum L., Lavandula angustifolia Mill., Rosa damascena Mill., R. canina L., Thymus longicaulis subsp. longicaulis C.pres 1., Tussilago farfara L., Digitalis lanata Ehrh., D. lamarckii Ivan., Crocus sativus L., Capsicum annuum L., Origanum syriacum subsp. bevanii (Holmes) Greuter \& Burdet, Ecballium elaterium (L.) A. Rich., Sinapis arvensis L., Papaver somniferum L., P. bracteatum Lindl., Capparis spinosa L., Coriandrum sativum L., Petroselinum crispum (Mill.) A. W. Hill., Silybum marianum (L.) Gaertn., Ziziphus jujuba Mill., Peganum harmala L., Carthamus tinctorius L., Rumex acetosella L., Dianthus caryophyllus L., Ocimum basilicum L., Mentha spicata subsp. spicata L. taksonlarının biyoteknolojik yöntemlerle üretimi, çoğaltımı ve ıslah çalışmalarına yönelik 1984-2019 yılları arasında yapılan araştırmalar derlenmiştir. Tıbbi ve aromatik bitkilere olan ihtiyacı karşılamaya yönelik üretimin yapılabilmesi ve istenen verimin alınabilmesi için, bitkilerde in vitro şartlarda organogenesis, somatik embriyogenesis gibi biyoteknolojik yöntemler kullanılabilmektedir. Aynı zamanda biyoteknolojik yöntemlerle çeşitli ıslah çalışmaları da gerçekleştirilebilmektedir. Tıbbi ve aromatik bitkilerde klasik çoğaltım yöntemlerinin dışında in vitro çoğaltım teknikleri ile yoğun ve klonal bir çoğaltımın sağlanması, büyük bir potansiyel olarak ortaya çıkmaktadır.

Anahtar kelimeler: Organogenesis, somatik embriyogenesis, tıbbi ve aromatik bitki.

\section{Giriş}

İnsanlık tarihi boyunca bitkilerin, sağlığı korumak ya da geri kazanmak amacıyla kullanıldığı bilinmektedir. Mezopotamya bölgesinde yaşamış Asurlular, Akatlar ve Sümerler gibi medeniyetlerde, bitkilerden ve hayvansal ürünlerden tedavi amaçlı ilaçların üretilerek kullanıldığ M.Ö. 3000 yıllarına ait ilk yazılı belge niteliğinde olan Ninova tabletlerinde belirtilmiştir (Genç \& Kaçar, 2012). M.Ö. 2500 yıllarında da Çin'de uygulanan tıbbi yöntemlerle büyük benzerlik gösteren ve Hint bölgesinde uygulanan tıbbın en önde gelen isimlerinden olan Rig Veda, eserlerinde birçok şifalı bitki ve bitkisel üründen söz etmiştir. Eski Yunan medeniyetinde Eskulap ve modern tıbbın da atası sayılan Hipokrat da, kitaplarında 400 civarında bitki ve bitkisel ürünün tedavi amaçlı kullanımından bahsetmişlerdir. Tibbi ve aromatik bitkiler, insanlık tarihi boyunca deneme yanılma yöntemleri ile birlikte ve günümüzde de modern eczacılık ve tıp aracılığı ile insan, hayvan ve bitki sağlı̆̆ı için kullanılmaktadır (Faydaoğlu \& Sürücüoğlu, 2011; Genç \& Kaçar, 2012; Mert \& Dağıstan, 2016).

İnsanoğlu, bitkilerin kök, yaprak, çiçek, meyve gibi kısımlarının hangilerinin tedavi edici etkileri olduğunu deneme/yanılma, tesadüflerle veya hayvanların tükettiği bitkileri gözlemleyerek öğrenmiştir. Bitkiler o dönemlerde de gelişi güzel değil, dönemin filozoflarının önerilerine göre kullanılmıştır. İlerleyen zamanlarda bitkilerin kimyasal yapıları aydınlatılmış ve içerdikleri etkili maddeler saf olarak izole edilmiştir. Böylece "saf ve standart ilaç" kavramının temelleri atılmıştır (Tanrıseven, 2013). Bunun en güzel örneği, söğüt ağacından salisilikasitin izole edilmesi ve yapısının aydınlatılmasıdır. 1890 yılında bu bileşikten basit bir kimyasal işlemle sentetik olarak elde edilen "Aspirin" (asetil salisilik asit) insanlığın yararına sunulmuştur. Günümüzde aslında modern tibbin yanında alternatif tıp olarak da 
isimlendirilen tedavi yöntemlerinin birçoğu, bilimsel olarak araştırılıp değerlendirildikten ve tabi ki etkinlikleri ispatlandıktan sonra insan hayatına girmeye başlamışlardır (Genç \& Kaçar, 2012).

Günümüz modern tıbbında kullanılan pek çok ilaç hammadde kaynağının bitkiler olduğu bilinmektedir. Avrupa'nın güneyi ile Güneybatı Asya floraları arasında bir köprü oluşturan Anadolu aynı zamanda üç fitocoğrafik bölgenin kesiştiği bir bölgedir. Birçok cins ve seksiyonun orijini ve farklılaşım merkezidir (Akman, 1995). Anadolu'nun zengin florası, birçok tıbbi ve aromatik bitkiye ev sahipliği yapmakla kalmayıp bununla birlikte pek çok bitkinin de gen merkezidir (Arslan, Baydar, Kızık, Arık, Şekeroğlu, \& Gümüşcü, 2015). Ancak tüm bu zenginliğe rağmen bitki popülasyonlarından ne tam manasıyla yararlanılmakta ne de kültürel olarak üretimi yapilmaktadir.

Anadolu'da florada doğal olarak bulunan bitkilerden; hem insan hem de hayvan hastalıklarının tedavisinde (Fitoterapi), çay, gıda, baharat, boya, reçine, insektisit, zamk, uçucu yağlarından faydalanma, ip ve sepet yapımı, meşrubat, kozmetik sanayinde kullanımı gibi halk arasında yaygın bir şekilde faydalanılmaktadır. Türkiye, Dünya'da tıbbi ve aromatik bitki ticaretinde önemli bir yere sahiptir. Ülkemizden, hem nihai ürün hem de bitkisel ilaç ve kimyasal sanayi için hammadde, gıda sektöründe kullanılan bitkisel kökenli katkı maddeleri, kozmetik ve parfüm sanayi için nihai ürün ve hammadde ile boya sanayi gibi önemli sektörlere de hammadde sağlanmaktadır (Arslan, Javani, \& Taher, 2016; Genç \& Kaçar, 2012;).

Bitki doku kültürü: Genel anlamda steril şartlar altında bitki hücre ya da organlarını elde etmek ve büyütmek için kullanılan teknikleri açıklayan bir kavramdır (Chawla, 2002; Özcan, Babaoğlu, \& Sancak, 2001;). Bitki biyoteknolojisinin önemli bir parçası olan in vitro çoğaltım yöntemleri, klasik yöntemlerle ıslahı zor veya tamamen imkânsız olan durumlarda çözüm sunmaktadır. Bu sayede hastalıktan, virüsten ve diğer zararlılardan arındırılmış sağlıklı bitkiler yetiştirebilmek, yoğun ve klonal çoğaltım yapabilmek, sekonder ve diğer değerli metabolitleri üretmek ve aynı zamanda miktarını artırılabilmek, verimsiz, yetişme olasılığı düşük olan bitkilerin yetiştirilebilmesi ve genetik çeşitliliğin sağlanması mümkündür. Tüm bunlar düşük maliyetli daha az iş gücüne gereksinim duyularak klasik yöntemlere göre daha hızlı bir üretim olanağı sağlamaktadır (Acar, İşkil, \& Bürün, 2017; Bayraktar, Öztürk, \& Arslan, 2017; Carimi, Tortorici, Pasquale, \& Crescimanno, 1998; Dilmen \& Göktürk, 2016; Güven \& Gürsul, 2014).

Biyoteknoloji Türkiye'de ormancıllk alanında yeni sayılabilecek bir bilim dalıdır ve ormancılıkta klasik yöntemlerle birlikte ülkemiz ekonomisine önemli katkılar sağlayacağı beklenmektedir. Ayrıca orman kaynaklarının korunması ve daha fazla yararlanılması hususunda, hem bölgesel hem de uluslararası süreçler biyoteknoloji uygulamalarını gündeme getirmiştir. Bunun bir yansıması olarak Avrupa Birliği kapsamında yürütülen "Eurosilva" şebekesinin hayata geçirilmesi kapsamında, biyoteknoloji araştırmalarının önemine vurgu yapılmış, asli ve tali orman ürünlerinin çoğaltımı, ıslahı ve korunması hususunda biyoteknolojiden daha fazla yararlanılması gerektiği vurgulanmıştır.
Türkiye ekonomisine katkı sağlayabilecek olan bazı tıbbi ve aromatik bitkilerin biyoteknolojik yöntemlerle üretim yöntemleri, çoğaltımı ve ıslah çalışmalarına yönelik araştırmalar derlenmiştir. In vitro ortamda kültüre alınmış ve çoğaltımı yapılmış bitkilerin listesi Türkçe isimleriyle birlikte Tablo 1'de verilmiştir (Güner, Aslan, Ekim, Vural, \& Babaç, 2012).

Tablo 1. In vitro kültürü yapılan bazı tıbbi aromatik bitkilerin Latince ve Türkçe isimleri

\begin{tabular}{|c|c|c|}
\hline & Bitkinin Latince İsmi & $\begin{array}{ll}\text { Bitkinin } & \text { Türkçe } \\
\text { İsmi }\end{array}$ \\
\hline $1-$ & Sideritis perfoliata $\mathrm{L}$. & Fincan çayı \\
\hline $2-$ & Sideritis stricta Boiss. \& Heldr. & Tilkikuyruğu çayı \\
\hline 3- & Sideritis erythrantha Boiss. \& Heldr. & Morçay \\
\hline $4-$ & Digitalis lamarckii Ivan. & Yüksükotu \\
\hline $5-$ & Digitalis lanata Ehrh. subsp. lanata. & Yünlü yüksükotu \\
\hline $6-$ & Leucojum aestivum $\mathrm{L}$. & Gölsoğanı \\
\hline 7- & Papaver somniferum $\mathrm{L}$. var. somniferum & Afyonçiçeği \\
\hline 8- & Papaver somniferum $\mathrm{L}$. & Haşhaş \\
\hline 9- & Papaver bracteatum Lindl. & Adamağusu \\
\hline $10-$ & Borago officinalis L. & Hodan \\
\hline $11-$ & Cuminum cyminum $\mathrm{L}$. & Acem kimyonu \\
\hline $12-$ & Coriandrum sativum L. & Kişniş \\
\hline $13-$ & Lavandula angustifolia Mill. & Lavanta \\
\hline 14- & Lavandula officinalis Chaix. (synonym) & Lavanta \\
\hline $15-$ & Silybum marianum (L.) Gaertn. & Devedikeni \\
\hline $16-$ & Rosa damascena Mill. & Isparta gülü \\
\hline $17-$ & $\begin{array}{l}\text { Thymus longicaulis C.Presl. subsp. } \\
\text { longicaulis }\end{array}$ & Aş kekiği \\
\hline $18-$ & Thymus vulgaris $\mathrm{L}$. & Kekik \\
\hline 19- & Tussilago farfara $\mathrm{L}$. & Öksürükotu \\
\hline $20-$ & Rumex acetosella $\mathrm{L}$. & Kuzukulağ1 \\
\hline 21- & Mentha spicata L. subsp. spicata & Eşek nanesi \\
\hline $22-$ & Cyclamen persicum Mill. & Alayaprak \\
\hline $23-$ & Ecballium elaterium (L.) A.Rich. & Eşek hıyarı \\
\hline $24-$ & Sinapis arvensis L. & Hardal \\
\hline $25-$ & Capparis spinosa $\mathrm{L}$. & Kebere \\
\hline $26-$ & Capsicum annuum $\mathrm{L}$. & Biber \\
\hline $27-$ & Rosa canina $\mathrm{L}$. & Kuşburnu \\
\hline $28-$ & Petroselinum crispum Mill. A.W.Hill. & Maydanoz \\
\hline $29-$ & Crocus sativus L. & Safran \\
\hline $30-$ & Ziziphus jujuba Mill. & Hünnap \\
\hline $31-$ & Peganum harmala $\mathrm{L}$. & Üzerlik \\
\hline $32-$ & Carthamus tinctorius L. & Aspir \\
\hline 33- & Dianthus caryophyllus L. & Karanfil \\
\hline $34-$ & Ocimum basilicum $\mathrm{L}$. & Fesleğen \\
\hline $35-$ & $\begin{array}{l}\text { Origanum syriacum L. subsp. bevanii } \\
\text { (Holmes) Greuter \& Burdet. }\end{array}$ & Hababa \\
\hline
\end{tabular}

\section{Bitkilerin Çoğaltımında Kullanılan in vitro Teknikler}

Türkiye'de yetişen bazı tıbbi ve aromatik bitkilerin çoğaltımında kullanılan somatik embriyogenesis, sürgün ucu kültürü, boğum kültürü, haploid bitki üretimi (androgenesis), biyoreaktör aracılığıyla üretim, somatik melezleme ve protoplast füzyonu gibi biyoteknolojik tekniklerle yapılan çoğaltım çalışmalarının; ne amaçla yapıldığı, hangi yöntemlerin uygulandığı ve elde edilen bulgular ile ilgili bilgiler sunulmuştur. Bitki çoğaltımında kullanılan embriyo kültürü, kallus kültürü hücre kültürü gibi diğer in vitro teknikler de, tıbbi ve aromatik bitkilerin çoğaltım çalışmalarında kullanılabilecek birer yöntem olarak ele alınabilmektedir.

\subsection{Somatik Embriyogenesis}

Bitkinin somatik dokularından kapalı iletim sistemine sahip bipolar bir embriyonun üretilmesini sağlayan aseksüel gelişme süreci, somatik embriyogenesis olarak adlandırılır (Cardoza, 2008; Özcan, Babaoğlu et al., 2001). Somatik embriyogenesis, in vitro çoğaltım teknikleri 
arasında oldukça önemli bir yöntemdir. Yoğun ve klonal bir çoğaltım için uygulanan bu teknikte embriyolar ya direkt olarak eksplant dokusundan ya da kallustan indirekt olarak oluşabilir. Genetik materyalin muhafazası, sentetik tohum üretimi, genetiği değiştirilmiş organizma üretimi, in vitro koşullarda çeşitli test ve çalışmalarda büyük bir potansiyel sağlayan bu teknikte başarı, genotipe, eksplant kaynağına, büyüme düzenleyici maddelere, azot kaynaklarına ve inkübasyon koşullarına bağlıdır. Somatik embriyolar aynı zamanda tohum olarak da kullanılabilmektedir. Biyoreaktörler aracılığıyla somatik embriyoların bol miktarda üretimi ve bunlardan sentetik tohum üretimi başarılı sonuçlar vermiştir (Fang, Wetten, \& Hadley, 2004). Bu tohumların genetik materyalin muhafazası amaciyla farklı tekniklerle (sıv1 azot içerisinde dondurarak, kurutma, yavaş büyütme vb.) uzun süre saklanması ve ihtiyaç duyulduğunda çimlendirilmesi mümkündür. Bu aslında, doğal çimlenme işlemini taklit eden bir olaydır. Türkiye'de bazı tıbbi aromatik bitkilerde yapilan somatik embriyogenesis çalışmalarının materyal metot ve sonuç kısımları Tablo 2 'de açıklanarak ifade edilmiştir.

Tablo 2. Tıbbi aromatik bitkilerde uygulanan somatik embriyogenesis çalışmaları

\begin{tabular}{l}
\hline Literatür, Tür, Eksplant \\
\\
- (Koçak et al., 2014) \\
- Cyclamen persicum Mill. (Domuz \\
Turpu) \\
- Boğum arası
\end{tabular}

Kültür Koşulları
MS (Murashige \& Skoog, 1962) besin ortamına: Fe-EDTA, pepton
$(250 \mathrm{mg} / \mathrm{L})$, myo-inositol $(100 \mathrm{mg} / \mathrm{L})$, glycine $(2.0 \mathrm{mg} / \mathrm{L}), \mathrm{NAA}$
$(0.5 \mathrm{mg} / \mathrm{L})$, thiamine $\mathrm{HCl}(0.1 \mathrm{mg} / \mathrm{L})$, pyridoxine-HCl $(0.5 \mathrm{mg} / \mathrm{L})$,
sukroz $(30 \mathrm{~g} / \mathrm{L})$, glukoz $(2 \mathrm{~g} / \mathrm{L})$, gelrite $(3.7 \mathrm{~g} / \mathrm{L}), 2,4-\mathrm{D}(2.0 \mathrm{mg} / \mathrm{L})$
ve $2 \mathrm{iP}(0.8 \mathrm{mg} / \mathrm{L})$ ekleyerek hazırlamıslardır. $22-25^{\circ} \mathrm{C}^{\prime}$ de karanlıta
inkübe etmişlerdir.

-(Ovecka, Bobak, Blehova, \& Kristin, 1997).

-Papaver somniferum L. (Haşhaş) -Somatik embriyogenesis

-(Başalma, Uranbey, Mirici, \& Özer, 2008).

- Carthamus tinctorius L. (Aspir) - Somatik embriyogenesis

- (Ljubinka, Snezana, Radmila, \& Mirjana, 1987).

- Rumex acetosella L. (Kuzukulağı)

- Somatik embriyogenesis
Farklı dozlarda NAA ve KIN'nin eklendiği MS (Murashige \& Skoog, 1962) ortamında kültüre alma çalışması yapmışlardır. Tüm kültüre alma ve çoğaltım aşamasında 16 saatlik fotoperiyot ve $25 \pm$ $2{ }^{\circ} \mathrm{C}$ sıcaklık uygulamışlardır. Elde edilen kallusları $0.1 \mathrm{mg} / \mathrm{L}$ NAA, $0.1 \mathrm{mg} / \mathrm{L} \mathrm{KIN}, 0.1 \mathrm{mg} / \mathrm{L}$ IAA ve $0.5 \mathrm{mg} / \mathrm{L}$ BAP içeren MS ortaminda alt kültüre almışlardır.

In vitro ortamda çimlendirilerek elde edilen filizlerdeki 1-2 mm çapındaki kotiledonlar, boğum kısımlarında ki sürgünler ve kalluslar \%3 sukroz ve \%0.8 agar içeren MS (Murashige \& Skoog, 1962) ortamina, farklı konsantrasyonlarda TDZ; $0.05,0.1$ ve 0.5 $\mathrm{mg} / \mathrm{L}$ ve IBA; 0.25 ve $0.5 \mathrm{mg} / \mathrm{L}$ hormonlarını içeren $(100 \times 10$ $\mathrm{mm}$ )'lik petri kaplarında kültüre almışlardır. Meristem kültürü kotiledon dan 14 gün sonrasında direk organogenesis ile elde etmişlerdir. Kotiledon boğumları $2-3 \mathrm{~cm}$ uzunluğunda ve meristem tiptekileri 1 - $2 \mathrm{~mm}$ uzunluğunda MS ortamında çeşitli konsantrasyonlar da BAP $(0.5$ ve $1.0 \mathrm{mg} / \mathrm{L})$ tek başına veya NAA (0.02 ve $0.2 \mathrm{mg} / \mathrm{L}$ ) Magenta kaplarında (GA-7) kültüre almışlardır.

3-4 mm uzunluğunda steril edilen eksplantları kullanmışlardır. MS (Murashige \& Skoog, 1962) besin ortamina; thiamine $(1.0 \mathrm{mg} / \mathrm{L})$, pyridoxine $\mathrm{HCl}(1.0 \mathrm{mg} / \mathrm{L})$, NAA $(5.0 \mathrm{mg} / \mathrm{L})$ ve $\% 0.7$ agar eklemişlerdir. 3 farklı besin ortamı hazırlayıp: sürgünler \% 2 sukroz, BAP $(2.2 \mathrm{mg} / \mathrm{L})$ ve IAA $(0.17 \mathrm{mg} / \mathrm{L})$ ile muamele etmişlerdir; alt kültürlerde sadece $\% 6$ sukroz, mannitol veya sorbitol eklenerek ya da \% 6 'lık sukroz tek başına eklenerek ortam hazırlanıp kültüre almışlardır. Olgunlaşmış embriyolar \%6 sukroz BAP ve IAA olmaksızın sadece $\mathrm{GA}_{3}(10 \mathrm{mg} / \mathrm{L})$ eklenerek kültüre almışlardır. pH 7.2 ile 7.3 arasında ayarlamışlardır.

MS (Murashige \& Skoog, 1962) besin ortamına: IAA $(0.4 \mathrm{mg} / \mathrm{L})$, NAA $(0.4 \mathrm{mg} / \mathrm{L})$ eklenerek $\mathrm{pH} 5.7$ de $21-22^{\circ} \mathrm{C}^{\prime}$ de inkübasyon yapmışlardır.

\section{Sonuç}

\%80-95 oranında somatik embriyo elde etmişler, sürgün gelişimi, bitki oluşumu gözlemiş̧lerdir.

Çalışmada P. Somniferum L. bitkisinde $0.1 \mathrm{mg} / \mathrm{L}$ NAA, $0.1 \mathrm{mg} / \mathrm{L} \mathrm{KIN} \mathrm{içeren} \mathrm{MS}$ besin ortaminda kallus elde etmişlerdir. Sürgün oluşumundan önce kallus üzerinde küçük beyaz preembriyonik yapıları gözlemişlerdir.

En yüksek sürgün rejenerasyonu (\%33.33) ve en yüksek sayıda sürgün adeti (6.5) MS ortamina eklenen $0.5 \mathrm{mg} / \mathrm{L}$ TDZ ve 0.25 $\mathrm{mg} / \mathrm{L}$ IBA ile gözlemişlerdir. Meristem ve kalluslardan direk organogenesis ile 14-21 gün sonrası MS ortamında bulunan farklı dozlardaki BAP ve NAA'de gözlemişlerdir.

En yüksek embriyo gelişimi $\mathrm{GA}_{3}$ eklenen ortamda olmuştur.

Üç farklı tipte eksplant oluşmuş ve embriyo gelişimi gözlemişlerdir.
- Cuminum cyminum L. (Kimyon)

- Somatik embriyogenesis sonra gelişerek embriyo halinde anterlerin içerisinden görülebilir aşamaya ulaşmaktadır. Bu olay direkt androgenesis olarak adlandirılmaktadır. Bundan farklı olarak, bazı bitki türlerinde önce kallus meydana gelmekte ve akabinde kallustan organogenesis veya embriyogenesis vasıtasıyla haploid bitkiler oluşmaktadır. Bu ikinci oluşum yoluna da indirekt androgenesis denilmektedir. Haploid bitki üretimi amacıyla yapılan çalışmaların materyal metot ve sonuç kısımları Tablo 3' de belirtilmiştir.

\subsection{Somatik Hücre Melezlemesi, Protoplast Kültürü}

Somatik melezleme, prezigotik eşeysel uyuşmazlık gibi nedenlerden dolayı klasik yöntemlerle melezlemesi yapılamayan hibritlerin üretilmesinde gerek fiziksel gerekse kimyasal yöntemlerden faydalanılarak uygulanan bir kültür tekniğidir (Babaoğlu \& Özcan, 2001). Üretilen somatik melez hücreden, kallus uyarımı ve bundan bitkiye 
dönüşüm, sistemin en önemli parçasıdır. Genel anlamda bu işleme genetik kopyalama denilebilir ve bitkilerde yaklaşık 60 yıldan beri yapılagelmektedir (Ochatt \& Power, 1992). Protoplast yönteminde ise çok hücreli bitkilerde bitki hücreleri birbirlerine hücre duvarı yapısı ile bağlanmaktadırlar. Bir bitki hücresinin hücre duvarı uzaklaştırıldığında geriye kalan yapıya protoplast denilmektedir. Oluşturulan bu protoplastlar izotonik ortamda canlılığını sürdürerek, kendisine yeni bir hücre duvarı sentezlerler. Mitozla çoğalarak yeni hücre birliktelikleri oluşturan hücreler (mikrokallus), daha sonra bu yapıdan da yeni bitkiler meydana getirebilmektedir.

İşte bu yöntem bitkilerin totipotensi özelliğini ortaya açıç̧a koymaktadır. Yani her bir bitki hücresi kendisinden yeni bir bitki oluşturabilme kapasitesine sahiptir (Babaoğlu \& Özcan, 2001). Bu yöntemle yapilan çalışmaların materyal, metot ve sonuç kısımları Tablo 4' de açıklanarak ifade edilmiştir.

\subsection{Sürgün Ucu Kültüründe Biyoreaktör Kullanımı}

Biyoreaktörler, canlı organizma, hücre veya dokuların sıvı besi yeri içerisinde kültür ortamına zarar vermeden $\mathrm{pH}$, sıcaklık, hava temini, karıştırma ve taze besi yeri ekleme işlemlerinin yapılabildiği elektronik kontrole imkân sağlayan metal, cam veya plastikten üretilmiş tanktır. Biyoreaktör içerisindeki besin ortamının şartlarını yakından takip etmeye olanak tanıdığı gibi fiziksel ve kimyasal müdahaleye de elverişli bir sistemdir (Topçu \& Çölgeçen, 2015). Tablo 5'de biyoreaktör ile çoğaltımı sağlanan tıbbi aromatik bitkilerin, çoğaltım aşamasının materyal metot ve sonuç kısımları gösterilmiştir.

\subsection{Sürgün Ucu ve Boğum Kültürleri}

Totipotensi özelliğine sahip bitki kısımlarından alınan (tek hücre, polen tanesi, embriyo, tohum, gövde, sürgün, kök, kallus vb.) eksplantların, besin ortamları üzerinde ve steril koşullarda yeni bitkilerin elde edilmesi amacıyla kültüre alınmasına mikroçoğaltım denir. Bitkilerin yetiştirilmesine uygun besin ortamı, bitki büyüme düzenleyici madde ve kültür ihtiyaçları yeteri kadar biliniyorsa mikroçoğaltım tekniği aracılığı ile her tür bitkinin üretimi ve çoğaltımı mümkündür (Ayabe \& Sumi, 2001; Hartman \& Kester, 1975; Uçar \& Turgut, 2009; Wang et al., 2006). Bitkilerin in vitro şartlarda üretiminde tekniğin adlandırılması, kullanılan eksplantın (embriyo, meristem, anter, boğum, hücre vb.) özelliğine göre olmaktadır. Ancak çoğunlukla üretimde kallus, boğum, boğum arası yöntemi, sürgün ucu, adventif sürgün ya da tomurcuklardan rejenerasyon gibi teknikler kullanılmaktadır (Mansuroğlu \& Gürel, 2001). Tablo 6'da sürgün, boğum, boğum arası, kök çimlendirme yöntemleri ile üretilen bitkilerin materyal metot ve sonuç kısımları açıklanarak anlatılmıştır.

Tablo 3. Capsicum annuum L.' da anter kültürü

\begin{tabular}{|c|c|c|}
\hline Literatür, Tür, Eksplant & Kültür Koşulları & Sonuç \\
\hline $\begin{array}{l}\text {-(Çağlar et al., 2004). } \\
\text {-Capsicum annuum L. } \\
\text { (Kırmızıbiber) } \\
\text { - Kırmızı pul biber olarak } \\
\text { kullanılan biberin anterleri }\end{array}$ & $\begin{array}{l}\text { Eksplantlar MS (Murashige \& Skoog, 1962) temel besin ortamında } \\
\text { kültüre almışlardır. Ayrıca MS ortamına: myo-inositol (100 mg/L), } \\
\text { sukroz ( } 30 \mathrm{~g} / \mathrm{L}) \text { ve agar }(8 \mathrm{~g} / \mathrm{L}) \text { ilave edilip. Büyüme düzenleyici } \\
\text { madde olarak ise: NAA }(2.0,4.0,6.0 \mathrm{mg} / \mathrm{L}) \text { ve } 2,4-\mathrm{D}(1.0,2.0,3.0 \text {, } \\
4.0 \mathrm{mg} / \mathrm{L}) \text { ile BAP }(0.1,1.0,2.0,3.0 \mathrm{mg} / \mathrm{L}) \text { ve KIN }(0.1,1.0,5.0 \\
\text { mg/L) eklemişlerdir. }\end{array}$ & $\begin{array}{l}\text { In vitro şartlarda üç binden fazla anter } \\
\text { kültüre almışlardır. Bunlardan } 284 \text { tanesi } \\
\text { kallus meydana getirirken, doğrudan } \\
\text { embriyogenesis de başarı } \\
\text { sağlayamamışlardır. Kırmızı biberlerden } \\
\text { Kahramanmaraş çeşidinde doğrudan } \\
\text { embriyogenesis yalnızca BAP }(0.1 \mathrm{mg} / \mathrm{L})+ \\
\mathrm{NAA}(4 \mathrm{mg} / \mathrm{L})+\text { aktif karbon }(\% 0.2)+ \\
\text { AgNO }(10 \mathrm{mg} / \mathrm{L}) \text { içeren MS besin } \\
\text { ortamına dikilmiş olan anter eksplantlar da } \\
\text { oluşmuş ve embriyo meydana getirme } \\
\text { oranı ise } \% 2.8 \text { olarak belirlemişlerdir. }\end{array}$ \\
\hline
\end{tabular}

Tablo 4. Protoplast kültürü ile çoğaltılan tıbbi aromatik bitkiler

\begin{tabular}{|c|c|c|}
\hline Literatür, Tür, Eksplant & Kültür Koşulları & Sonuç \\
\hline $\begin{array}{l}\text {-(Primard, Vedel, Mathieu, Pelletier } \\
\text { \& Chavre, 1988). } \\
\text { - Sinapis arvensis L. (Hardal) } \\
\text {-Hibritleme, protoplast }\end{array}$ & $\begin{array}{l}\text { Brassica hirta ve Brassica napus arasında Sinapis arvensis L. kullanılarak } \\
\text { hibritleme ile protoplast yöntemi çalışmışlardır. MS (Murashige \& Skoog, 1962) } \\
\text { besin ortamına: B besin ortamın mineral tuzları agar }(2.0 \mathrm{~g} / \mathrm{L}) \text {, gelrite }(3.0 \mathrm{~g} / \mathrm{L}) \text {, } \\
\text { sakkaroz }(30 \mathrm{~g} / \mathrm{L}), \text { mannitol }(10 \mathrm{~g} / \mathrm{L}), \mathrm{BAP}(0.5 \mathrm{mg} / \mathrm{L}), \mathrm{IBA}(0.5 \mathrm{mg} / \mathrm{L}) \\
\text { eklenerek hazırlamışlardır. pH } 7.2 \text { olarak ayarlanıp, } 25^{\circ} \mathrm{C}^{\prime} \text { de } 16 / 8 \text { saat } \\
\text { aydınllk/ karanllk şartlarda inkübe etmişlerdir. }\end{array}$ & $\begin{array}{l}\text { 2-4 hafta sonunda sürgün } \\
\text { gelişimi gözlemişlerdir. }\end{array}$ \\
\hline
\end{tabular}

Tablo 5. Biyoreaktör aracılığıyla çoğaltılan tıbbi aromatik bitkiler

\begin{tabular}{|c|c|c|}
\hline Literatür, Tür, Eksplant & Kültür Koşulları & Sonuç \\
\hline $\begin{array}{l}\text { - (Georgiev et al., 2012). } \\
\text { - Leucojum aestivum L (Göl soğanı) } \\
\text { - Boğum, boğum arası ve sürgünler }\end{array}$ & $\begin{array}{l}\text { Biyoreaktör tankları içine } 80 \text { adet sürgün olacak şekilde } 18^{\circ} \mathrm{C}, 22^{\circ} \mathrm{C} \text { ve } 26^{\circ} \mathrm{C}^{\prime} \text { de } \\
\text { dikim yapmıslardır. MS (Murashige \& Skoog, 1962) besin ortamına: sakkaroz } \\
(30 \mathrm{~g} / \mathrm{L}) \text {, agar ( } 5.5 \mathrm{~g} / \mathrm{L}) \text {, NAA }(1.15 \mathrm{mg} / \mathrm{L}) \text { ve BAP }(2 \mathrm{mg} / \mathrm{L}) \text { eklemişlerdir. } \\
\text { Sürgünler } \\
26^{\circ} \mathrm{C}^{\prime} \text { de } 16: 8 \mathrm{~h} \text { (1şık: karanlık) aydınlık koşullarda, } 110 \mu \mathrm{mol}\left(\mathrm{m}^{2 \mathrm{~s}} \text { SYLVANIA }\right. \\
\text { Gro-Lux) floresan ışığında büyümeye bırakmışlardır. (F18W/GRO-LUX). }\end{array}$ & $\begin{array}{l}80 \text { adet sürgünün başarılı bir } \\
\text { şekilde gelişme gösterdiğini } \\
\text { tespit etmişlerdir. }\end{array}$ \\
\hline $\begin{array}{l}\text { - (Panizza \& Tognoni, 1992). } \\
\text { - Lavandula officinalis Mill. (Lavanta) } \\
\text { - Sürgün arası }\end{array}$ & $\begin{array}{l}\text { Biyoreaktör tankları } 25^{\circ} \mathrm{C} \text { de } 16: 8 \mathrm{~h} \text { (ışık: karanlık) aydınlık koşullarda } \\
\text { ayarlamışlardır. MS (Murashige \& Skoog, 1962) besin ortamına: sakkaroz ( } 30 \\
\text { g/L), agar }(6 \mathrm{~g} / \mathrm{L}) \text {, ve büyüme düzenletici olarak NAA, IBA, ve IAA nın farklı } \\
\text { dozları eklenip inkübe etmişlerdir. }\end{array}$ & $\begin{array}{l}\text { En yüksek köklendirme MS } \\
\text { besin ortamina IAA (1 } \\
\text { mg/L) ve IBA (1 mg/L) } \\
\text { eklendiğinde gözlenmişken, } \\
\text { NAA }(0.5 \mathrm{mg} / \mathrm{L})^{\prime} \text { nin tek } \\
\text { başına eklenmesiyle en } \\
\text { yüksek sürgün gelişimi } \\
\text { gözlemişlerdir. }\end{array}$ \\
\hline
\end{tabular}


Tablo 6. Sürgün, boğum ve boğum arası yöntemleri ile üretilen yapılan tıbbi aromatik bitkiler

\begin{tabular}{|c|c|}
\hline Literatür, Tür, Eksplant & Kültür Koşulları \\
\hline $\begin{array}{l}\text {-(Uçar \& Turgut, 2009). } \\
\text { - Sideritis perfoliata L., Sideritis } \\
\text { stricta Boiss. \& Heldr., } \\
\text { Sideritis erythrantha Boiss. \& } \\
\text { Heldr. (Dağ çayı) } \\
\text {-Yaprak, yaprak sapı, boğum, } \\
\text { boğum arası tohum }\end{array}$ & 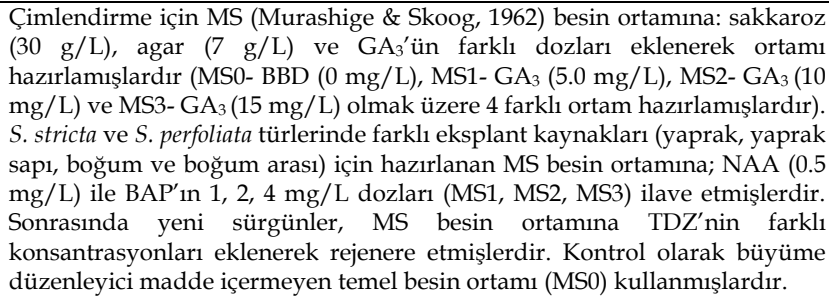 \\
\hline
\end{tabular}

-(Yücesan at al., 2018). -Digitalis lanata Ehrh. subsp. lanata (Yünlü yüksük otu) -Sürgün rejenerasyonu

-(Karaoğlu, 2004) -Leucojum aestivum L. (Göl soğani) -Yapraklardan ve olgunlaşmış embriyolardan doku kültürü yolu ile çoğaltım

-(Daneshvar Royandazag, 2005) -Papaver bracteatum Lindl. (Haşhaş) -Adventif sürgün rejenerasyonu, Hipokotil, kotiledon ve hipokotil kotiledon kısımları kullanmışlardır

- (Meriç, Tuman, Ayan, \& Atak, 2019).

- Lavandula angustifolia Mill. (Lavanta)

- Sürgünlerden doku kültürü ile in vitro çoğaltım

- (Saker, Gengaihi, Kamel, \& Farid, 2010).

- Ecballium elaterium (L.) A.

Rich. (Eşek hıyarı)

- Doku kültürü

- (Aawad, Khateeb, \& AlEkbal, 2006).

- Digitalis lamarckii Ivan.

(Yünlü yüksük otu)

- Çimlendirme için tohum,

boğum arası boğum, kök,

gövdeden $1 \mathrm{~cm}$ uzunluğunda

eksplant

-(Whipkey, James, \& Janick, 1988).

- Borago officinalis L. (Hodan)

- Sürgün, yaprak, yaprak

sapı, boğum

-(Gopi \& Ponmurugan, 2006)

-Ocimum basilicum L.

(Fesleğen)

- Boğum arası ve boğum
Steril edilen Digitalis lanata Ehrh. subsp. lanata (yüksük otu) tohumları $25 \mathrm{ml}$ MS (Murashige and Skoog 1962) $30 \mathrm{~g} / \mathrm{L}$ sukroz, $8 \mathrm{~g} / \mathrm{L}$ Plant agar ihtiva eden ortamda petri kaplarına in vitro ekmişlerdir.

* 6 hafta sonra gelişen yeni filizlerden $0.5 \mathrm{~cm}$ uzunluğunda eksplantlar alarak $(0.25,0.50,1.0,2.0 \mathrm{mg} / \mathrm{L})$ IAA, NAA, IBA büyüme düzenleyicilerini ihtiva eden $330 \mathrm{ml}$ 'lik MS ortamında kültüre almışlardır.

Besin ortamı olarak MS (Murashige ve Skoog 1962) ve N6 (Chu vd. 1975) mineral tuzları ve vitaminleri kullanmıştır. İki farklı eksplant tipi (soğan pul yaprakları ve olgunlaşmamış embriyolar) kullanılmış olup, her iki eksplant tipi için de farklı ortamlar kullanmışlardır. Olgunlaşmamış embriyolardan soğancık oluşumu 4 farklı ortam üzerinde ve 4 ayrı aşamada yürütmüşlerdir. Bu ortamlar; a) Kallus teşvik ortamı (KTO): N6 mineralleri ve vitaminleri, 2.3 $\mathrm{g} / \mathrm{L}$ L-prolin, $200 \mathrm{mg} / \mathrm{L}$ kazein hidrolisat, $20 \mathrm{~g} / \mathrm{L}$ sukroz, BAP (1, 2 ve 4 $\mathrm{mg} / \mathrm{L}$ dozlarinda), NAA (0.5, 1 ve $2 \mathrm{mg} / \mathrm{L}$ dozlarinda), $2.5 \mathrm{~g} / \mathrm{L}$ gelrite b) Embriyo geliștirme ortamı (EGO): Kallus teşvik ortamı ve $30 \mathrm{~g} / \mathrm{L}$ mannitol c) Embriyo olgunlaştırma ortamı (EOO): MS mineralleri ve vitaminleri, 60 g/L sukroz, $7 \mathrm{~g} / \mathrm{L}$ agar d) Sürgün oluşturma ortamı (SOO): MS, $20 \mathrm{~g} / \mathrm{L}$ sukroz, $7 \mathrm{~g} / \mathrm{L}$ agar

Denemelerde MS mineral, tuz ve vitaminleri (Murashige \& Skoog 1962) ile $\% 3$ sukroz içeren ve \%0.75'lik agar (type A, Sigma) ile katılastırılan temel Adventif sürgün rejenerasyonu amaciyla Papaver bracteatum' un 7 ve 18 nolu kapları içerisinde \%3 sukroz içeren ve \%0.8 agar ile katılaştırılan MS besin hatlarından

ortamında $19 \pm 1{ }^{\circ} \mathrm{C}^{\prime}$ de 16 saat ışı ve 8 saat karanlık foto periyodunda alınan, hipokotil-kotilodon eksplantlarda çimlendirmişlerdir. Her biri 4-5 mm uzunluğunda parçalara ayrılarak sırasıyla 7 . hatta en iyi sonuç $1 \mathrm{mg} / \mathrm{L}$ rejenerasyon ortamına konulmuş, çalışmada uygulanan forcing metodunda Kinetin, 0.5 eksplantlar yüksek oranda 2,4-D, NAA ve IBA $15 \mathrm{mg} / \mathrm{L}$ içeren MS mg/L NAA ve $0.1 \mathrm{mg} / \mathrm{L} \mathrm{GA}_{3}$ içeren MS ortamlarında 3 gün süresinde bekletildikten sonra $0.24 \mathrm{mg} / \mathrm{L} \mathrm{2,4-D}$ ve 0.19 ortamda ve 18 . hattında Kinetin, $2.00 \mathrm{mg} / \mathrm{L}$ $\mathrm{mg} / \mathrm{L}$ NAA ve vitaminler $(2 \mathrm{mg} / \mathrm{L}$ glisine, $0.5 \mathrm{mg} / \mathrm{L}$ nikotinik asit, $0.5 \mathrm{mg} / \mathrm{L}$ NAA ve $0.1 \mathrm{mg} / \mathrm{L} \mathrm{GA}, 2.00 \mathrm{mg} / \mathrm{L} \mathrm{Kinetin}$, pyridoxine, $200 \mathrm{mg} / \mathrm{L}$ miyoinositol ve $0.5 \mathrm{mg} / \mathrm{L}$ thiamine ) içeren MS $2.00 \mathrm{mg} / \mathrm{L}$ NAA ve $0.1 \mathrm{mg} / \mathrm{L} \mathrm{GA}_{3}$ içeren ortamına aktarmışlardır. 120 gün sonra 2,4-D, NAA ve değişik vitaminler ortamlardan elde etmişlerdir. Köklenme de içeren MS ortamında gelişen bitkicikler aynı ortama alt kültüre almışlardır. en iyi sonucu $0.5 \mathrm{mg} / \mathrm{L}$ IBA içeren Köklenmeyi sağlamak için, rejenere olan sürgünler $0.25,0.50$ ve $1.0 \mathrm{mg} / \mathrm{L}$ ortamlardan elde etmişlerdir. IBA içeren MS besin ortamına almışlardır.

Bitkinin sürgün kısımlarından aldıkları eksplantları kallus, sürgün ve kök oluşumu için in vitro ortamda doku kültürü yöntemi ile kültüre almıştır. Bunun için MS ortamına farklı dozlarda $(1 \mathrm{mg} / \mathrm{L}, 1.25 \mathrm{mg} / \mathrm{L}, 2 \mathrm{mg} / \mathrm{L}) 2,4-\mathrm{D}$, BAP, IBA, NAA ekleyerek farklı ortamlar hazırlamıştır.

Misır da El-Arish kentinde yetişmekte olan Ecballium bitkisinden eksplantlar almışlardır. Steril edilen tohumları MS ortamına \%3 sukroz ve $7 \mathrm{gr} / \mathrm{L}$ agar

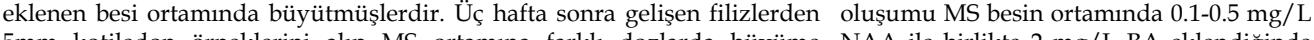
$5 \mathrm{~mm}$ kotiledon örneklerini alıp MS ortamına farklı dozlarda büyüme NAA ile birlikte $2 \mathrm{mg} / \mathrm{L}$ BA eklendiğinde

düzenleyicileri NAA ve BA eklenerek kültüre almışlardır. Kallusları elde etmişlerdir. geliştirmek için de MS ortamına $0.2 \mathrm{mg} / \mathrm{L}$ NAA ve $2 \mathrm{mg} / \mathrm{L}$ BA eklemişlerdir.

MS besin ortamına bir oksin (BBD), farklı dozlarda IAA, IBA, NAA $(0.05,0.1$, 0.5 ve $1.0 \mathrm{mg} / \mathrm{L}$ ) ilave edilmis, $\mathrm{pH}$ 5.7'ye ayarlanarak hazırlanan En iyi sürgün gelişimi IBA (0.5 mg/L) ortamlardaki bitkiler $25^{\circ} \mathrm{C}^{\prime}$ de inkübe etmişlerdir. eklenmiş ortamda kaydetmişlerdir.

En yüksek çoğaltım \%64.7 oranında MS ortamina eklenen $2 \mathrm{mg} / \mathrm{L}$ BAP ile gözlemiştir. En iyi sürgün gelişimi ise \%95.6 oraninda MS ortamina NAA ve IBA 'nin çeşitli dozlarda birlikte eklenmesi ile elde etmiştir. En yüksek köklenme ise \%60 oraninda MS ortaminda $1.25 \mathrm{mg} / \mathrm{L}$ IBA eklenmesi ile elde etmiştir. En iyi kallus gelişimi ise \%66 oranında MS besin ortamina $2 \mathrm{mg} / \mathrm{L} \mathrm{2,4-D}$ ve $2 \mathrm{mg} / \mathrm{L}$ BAP eklenmesi ile elde etmiştir.

MS besin ortamına: $B_{5}$ besin ortamının vitamin tuzları ile birlikte thiamine En yüksek verim: NAA $(0.5 \mathrm{mg} / \mathrm{L})$ ve $(0.3 \mathrm{mg} / \mathrm{L}), 2,4-\mathrm{D}$ pyridoxine-HCl, myo-inositol $(100 \mathrm{mg} / \mathrm{L})$, NAA $(0.5$ thiamine $(0.3 \mathrm{mg} / \mathrm{L})$ eklenen ortamda $\mathrm{mg} / \mathrm{L})$, glisin $(2 \mathrm{mg} / \mathrm{L})$, kazein hidrolizat $(1 \mathrm{~g} / \mathrm{L})$, sakaroz $(30 \mathrm{~g} / \mathrm{L})$ ve agar gözlemlemişlerdir. $(6 \mathrm{~g} / \mathrm{L})$ eklenip pH 5.7'ye ayarlanarak, ortama almışlardır.

MS (Murashige \& Skoog, 1962) besin ortamina BAP (1.0 mg/L), NAA (1.0 Maksimum büyüme BAP (1.0 mg/L) NAA $\mathrm{mg} / \mathrm{L}), \mathrm{KIN}(0.5 \mathrm{mg} / \mathrm{L})$ eklemişlerdir. İnkübasyon koşulları ise $25^{\circ} \mathrm{C}$ sıcaklık $(1.0 \mathrm{mg} / \mathrm{L})$ ve $\mathrm{KIN}(0.5 \mathrm{mg} / \mathrm{L})$ eklenmiş ta ve karanlığa maruz bırakarak yapmışlardır. ortamda gözlemişlerdir. 


\section{Literatür, Tür, Eksplant}

-(Stephen \& Jayabalan, 1998). - Coriandrum sativum $\mathrm{L}$.

(Kişniş)

- Çimlendirme için tohum ve

sürgün, boğum, boğum arası

-(Moallem, Behbahani,

Mousavi, \& Karimi, 2012).

-Rosa canina L. (Kuşburnu)

-Kök, tohum, sürgün, boğum,

boğum arası

- (Vandermoortele, Billard, Boucaud, \& Gaspar, 1996).

- Petroselinum crispum (Mill.)

A. W. Hill. (Maydanoz)

- Boğum, boğum arası, kök

-(Abbasi, Khan, Mahmood,

Mushtaq, Chaudhary, \&

Khan, 2010).

-Silybum marianum (L.)

Gaertn. (Devedikeni)

-Boğum, boğum arası sürgün

-(Ünaldı, 2007; Acar et al.,

2017).

-Crocus sativus L. (Safran)

-Yaprak, yaprak sapı, sürgün

-(Arıcı, Şan, \& Kazaz, 2017).

-Rosa damascena Mill. (Isparta

Gülü)

-Sürgün, boğum, boğum arası

-(Özüdoğru, Kaya, Kırdok,

İşsever, \& Öztürk, 2011).

- Thymus longicaulis subsp.

longicaulis C. presl.

(Aşkekikiği)

- Kök, boğum ve boğum arası

-(Soliman \& Hegazi, 2013).

- Ziziphus jujuba Mill.

(Hünnap)

- Boğum ve boğum arası

-(Ren, Rei, \& Li, 2017).

- Tussilago farfara L. (Öksürük otu)

- Çimlendirme, boğum ve

boğum arası

- (Harshan \& Nag, 1984; Saini \& Jaiwal, 2000).

- Peganum harmala L. (Üzerlik)

- In vitro ortamda

çimlendirilen tohumların

hipokotil kısımları

- (Özdemir, Uğur, Yıldırım \& Kahrizb, 2015).

- Mentha spicata subsp. spicata

L. (Bahçe nanesi)

- Boğum ve boğum arası

- (Çetin, Kazaz \& Göktürk, 2007).

- Dianthus caryophyllus L.

(Karanfil)

- Sürgün ucu (0.5 - 1 cm)

-(Türker \& Hatipoğlu, 2018).

- Origanum syriacum subsp. bevanii (Holmes) Greuter \& Burdet (Dağ kekiği, hababa) - Yaprak diski, boğum,

tomurcuk

\section{Kültür Koşulları}

SH besin ortamına farklı dozlarda NAA ve $\mathrm{GA}_{3}$ eklemişlerdir. Dozlar:

*NAA $(0.05 \mathrm{mg} / \mathrm{L})+\mathrm{GA}_{3}(0.5 \mathrm{mg} / \mathrm{L})$

*NAA $(0.1 \mathrm{mg} / \mathrm{L})+\mathrm{GA}_{3}(0.5 \mathrm{mg} / \mathrm{L})$

NAA $(0.1 \mathrm{mg} / \mathrm{L})+\mathrm{GA}_{3}(0.5 \mathrm{mg} / \mathrm{L})$

NAA $(0.15 \mathrm{mg} / \mathrm{L})+\mathrm{GA}_{3}(0.5 \mathrm{mg} / \mathrm{L})$

$\mathrm{NAA}(0.2 \mathrm{mg} / \mathrm{L})+\mathrm{GA}_{3}(0.5 \mathrm{mg} / \mathrm{L})$

MS besin ortamina aktif kömür $(3 \mathrm{mg} / \mathrm{L})$ ve BAP $(0.25 \mathrm{mg} / \mathrm{L}), \mathrm{GA}_{3}(1 \mathrm{mg} / \mathrm{L})$

$\mathrm{GA}_{3}(0.5 \mathrm{mg} / \mathrm{L})+\mathrm{BAP}(0.25 \mathrm{mg} / \mathrm{L}), \mathrm{GA}_{3}(1 \mathrm{mg} / \mathrm{L})+\mathrm{BAP}(0.25 \mathrm{mg} / \mathrm{L})$, ve GA

$(1.5 \mathrm{mg} / \mathrm{L})+\mathrm{BAP}(0.25 \mathrm{mg} / \mathrm{L})$. Köklendirme için; aktif kömür $(3 \mathrm{mg} / \mathrm{L})$ ve

$\operatorname{BAP}(0.25 \mathrm{mg} / \mathrm{L})$, NAA $(1 \mathrm{mg} / \mathrm{L})$, NAA $(0.5 \mathrm{mg} / \mathrm{L})+\mathrm{BAP}(0.25 \mathrm{mg} / \mathrm{L})$, NAA

$(1 \mathrm{mg} / \mathrm{L})+\mathrm{BAP}(0.25 \mathrm{mg} / \mathrm{L})$ ve NAA $(1.5 \mathrm{mg} / \mathrm{L})+\mathrm{BAP}(0.25 \mathrm{mg} / \mathrm{L})$ eklenerek hazırlamışlardır.

MS ortamina farklı 9 (BBD) kombinasyonu denemislerdir. BAP 'den (0 - En iyi sürgün rejenerasyonu BAP (0.562 $0.562-1.125 \mathrm{mg} / \mathrm{L}$ ile) NAA: $0,0.465$ veya $0.93 \mathrm{mg} / \mathrm{L}$ tek başına eklenerek $\mathrm{mg} / \mathrm{L})$ ve NAA $(0.465 \mathrm{mg} / \mathrm{L})$ eklenen ortamlar hazırlamışlardır. ortamda gözlemlemişlerdir.

MS besin ortamina BAP $(0.25,0.5,1.0,2.0,5.0$, ve $10 \mathrm{mg} / \mathrm{L})$ veya $\mathrm{GA}_{3}$ ile NAA $(1.0 \mathrm{mg} / \mathrm{L})$ eklenerek hazırlamışlardır.

BAP $(1 \mathrm{mg} / \mathrm{L})$ ve NAA' da $\% 80$ oranında büyüme; BAP 'de (5 mg/L) \%90 oranında büyüme gözlemlemişlerdir.

MS besin ortamina farklı dozlarda NAA ve BAP eklenerek ortamlar hazırlamışlardır.

Besin ortamı olarak MS kullanmışlardır. Besin ortamına: agar $(7.5 \mathrm{~g} / \mathrm{L})$ ve sakaroz (30 g/L) ilave etmişlerdir. Ortamın pH'sı 5.8 olarak ayarlanmış ve agar ilavesinin ardından isitılarak eritilen besin ortamları 5'er $\mathrm{ml}$ olacak şekilde tüplere dağıtılmıştır. 32 farklı BBD kombinasyonu denemişlerdir.

MS besin ortamina IAA, IBA, NAA ile birlikte 2,4-D (BBD) $(0.01,0.05,0.1$ veya $1.0 \mathrm{mg} / \mathrm{L}$ ) dozlarında eklemişlerdir. Köklendirme için; MS Ortamına: KIN (1.0 mg/L) ve GA 3 (0.3 mg/L) eklemişlerdir.

MS besin ortamına: $\% 3(\mathrm{w} / \mathrm{v})$ sakaroz ve bitkisel gelrite $(2.5 \mathrm{~g} / \mathrm{L})$ ve farklı oranlarda (BBD) kullanmıslardır. Bunlar; sitokininlerden: BAP, $2 \mathrm{iP}$ ve TDZ ile oksinlerden: NAA, IAA ve IBA' dir.

En iyi büyüme MS besin ortamina NAA $(0.05 \mathrm{mg} / \mathrm{L})+2 \mathrm{iP}(2 \mathrm{mg} / \mathrm{L})$ eklendiğinde gözlemlemişlerdir.

En iyi gelişim \%96.2 oranında 6 numaralı MS besin ortaminda: BAP $(3.0 \mathrm{mg} / \mathrm{L})+2,4-$ $\mathrm{D} \quad(2.0 \mathrm{mg} / \mathrm{L}) \quad(\mathrm{BBD})$ eklendiğinde MS besin ortamında 6 farklı (BBD) kombinasyonu eklenerek kültüre alma gözlemlemişlerdir. Tohumların çimlenmesi çalışması denemişlerdir. Bu 6 farklı ortama farklı dozlarda KIN, IBA, 2,4-D, ise KIN $(1.0 \mathrm{mg} / \mathrm{L})$ ve IBA $(0.3 \mathrm{mg} / \mathrm{L})$ BAP (BBD) eklemişlerdir.

eklenmesiyle $\% 91$ oranında olurken, en iyi kök gelişimi \%95.22 oranında MS besin ortamina IBA $(0.2 \mathrm{mg} / \mathrm{L}) \quad$ (BBD) eklendiğinde gözlemlemişlerdir.

En iyi sürgün gelişimi MS ortamına 1.125

İlk önce \%0.8 agar ve \%3 sakaroz ile hazırlanan ortama tohumlar ekilmiş. Cimlenen tohumlar MS besin ortamina BAP olmadan yalnızca 0.04 ve 0.09 $\mathrm{mg} / \mathrm{L}$ oranlarında NAA eklenerek kültüre almışlardır. Farklı dozlarda BAP, $\mathrm{NAA}$ ve $\mathrm{GA}_{3}$ eklenerek hazırlanan ortamlar da kültür çalışması denemişlerdir.

$\mathrm{mg} / \mathrm{L}$ BAP ve $0.02 \mathrm{mg} / \mathrm{L}$ NAA eklenmesiyle $\% 75 \quad$ oraninda gözlemlemişlerdir.

$\mathrm{GA}_{3}$ hormonu eklenen ortamda hiç büyüme gözlememişlerdir.

Kallusun meydana gelme oranları \%1.67 ile $\% 87.67$ arasındadır. Bu oluşum yüzdesinin BAP $(2 \mathrm{mg} / \mathrm{L})$ içeren MS besin ortamında en düşük miktarda ve BAP $(0.25 \mathrm{mg} / \mathrm{L})+$ NAA

Tohumların çimlendirilmesinde büyüme düzenleyici madde içermeyen MS $(0.50 \mathrm{mg} / \mathrm{L})$ içeren MS besin ortamında en besin ortam kullanmislardr. Hip $(0.25,0.50,1.0,2.0 \mathrm{mg} / \mathrm{L})$ ve $\mathrm{NAA}^{\prime}$ nin $(0,0.25,0.50 \mathrm{mg} / \mathrm{L}) 16$ farkl kombinasyonunu içeren MS besin ortamına dikmişlerdir. Köklendirme aşamasında ise MS besin ortamına IBA $(0.5 \mathrm{mg} / \mathrm{L})$ ilave edilerek dikip, $\mathrm{pH}$ 5.8 olarak ayarlamışlardır.

Sürgün oluşumu için MS besin ortamına ilave edilen KIN, BAP ve NAA' in farklı dozları denemişlerdir. Köklendirme için iki farklı ortam hazırlamışlardır. MS besin ortamına IBA $(2.0 \mathrm{mg} / \mathrm{L})$ ve BAP $(0.01 \mathrm{mg} / \mathrm{L})$ eklenerek ilk ortam, IBA $(0.05 \mathrm{mg} / \mathrm{L})$ ve BAP $(0.01 \mathrm{mg} / \mathrm{L})$ eklenerek diğer ortam hazırlamışlardır.

üksek miktarda olduğu ifade etmişlerdir. $\% 26.13$ ile $\% 97.33$ oranlarında sürgün rejenarasyonu elde etmişlerdir. Sürgün rejenerasyonu BAP $(0.50 \mathrm{mg} / \mathrm{L})+\mathrm{NAA}$ $(0.25 \mathrm{mg} / \mathrm{L})$ içeren MS besin ortaminda en az miktarda meydana gelirken, BAP (2.0 $\mathrm{mg} / \mathrm{L})+\mathrm{NAA}(0.25 \mathrm{mg} / \mathrm{L})$ içeren MS besin ortaminda ise en fazla miktarda meydana geldiğini açıklamışlardır.

En yüksek ortalama (5.97) sürgün sayısı: KIN $(2 \mathrm{mg} / \mathrm{L})+\mathrm{NAA}(0.02 \mathrm{mg} / \mathrm{L})$ içeren ortamdan, NAA $(0.02 \mathrm{mg} / \mathrm{L})+$ BAP $(2$ $\mathrm{mg} / \mathrm{L})$ eklenmiş ortama alınan sürgünlerden elde etmişlerdir.

Kardeşlenen sürgünler tepe veya yan MS besin ortamına 2,4-D veya NAA' in $(0 ; 0,25 ; 0,5 ; 0,75$ ve $1,0 \mathrm{mg} / \mathrm{L})$ dozları tomurcuk eksplantlarından gelişmiştir. BAP ile BAP veya KIN 'in $(0 ; 0,5 ; 1,0 ; 1,5$ ve 2,0 mg/L) dozları eklemişlerdir.
$(1,5 \mathrm{mg} / \mathrm{L})$ içeren ortamda en fazla sürgün gelişimi elde etmişlerdir. 
Literatür, Tür, Eksplant

-(Chalak, Elbitar, Cordahi, Hage \& Chehade, 2003).

- Capparis spinosa L. (Kapari)

- Tomurcuk, nodul, apikal

kisımlar, tohum
Kültür Koşulları

In vitro çoğaltım için Lübnan ekotipinin tohumları ve nodal tomurcukları

eksplant olarak kullanmışlardır. Tohumlar hormonsuz MS ortamına (\%71) Sürgünlerin yüksek köklenme tepkisi (\%87), ve steril su (\%64) vererek çimlendirmişlerdir. Oluşan filizler MS ortamına IAA çözeltisi (100 mg/L ) ile karanlıkta 4 BAP $(1.5 \mathrm{mg} / \mathrm{L})$, IBA $(0.05 \mathrm{mg} / \mathrm{L}) \pm \mathrm{GA}_{3}(0.1 \mathrm{mg} / \mathrm{L})$, eklenerek kültüre saatlik süre ile muamele dildikten sonra almışlardır. Her altı haftada bir 2-3 dügümlü sürgün bölümlerinin alt elde etmişlerdir.

kültürlenmesi ile aynı ortamda sürgün çoğaltımı yapmışlardır.

Bitkinin apikal ve nodül kısımlarından aldıkları 1-2 $\mathrm{cm}$ uzunluğundaki

eksplantlar 3 farklı MS ortamında inkübe etmişlerdir.

- MS1 (MS mineral tuzlardan $0.50 .327 \mathrm{mg} / \mathrm{L}$

myo-inositol ve $0.265 \mathrm{mg} / \mathrm{L}$ thiamine eklemişlerdir),

-MS2 (mineral tuzlardan modifiye dilmiş MS ortamı nitrattan az miktarda,

$\mathrm{CaCl}_{2}, \mathrm{MgSO}_{4}$ eklemişlerdir ve $0.325 \mathrm{mg} / \mathrm{L} \mathrm{m}$-inositol, $0.795 \mathrm{mg} / \mathrm{L}$ thiamine,

$32.56 .04 \mathrm{mg} / \mathrm{L}$ NAA, $0.102 \mathrm{mg} / \mathrm{L}$ pyridoxine- $\mathrm{HCl}$ and $3.036 \mathrm{mg} / \mathrm{L}$

$\mathrm{C}_{6} \mathrm{H}_{8} \mathrm{O}_{6}$ (askorbik asit)

- MS3 MS2 ile aynı şartları eklemişler sadece $\mathrm{CaCl}_{2}$ MS1'e göre beş kat

artırmışlardır.

\section{Sonuçlar ve Tartışma}

Moleküler yöntemlerle birlikte bitki biyoteknolojisini oluşturan in vitro çoğaltım teknikleri, kısa zamanda, yüksek kalitede ve bol miktarda ürün elde etmek amacıyla Dünya'da birçok ülkenin kullandığı bir üretim ve ıslah şeklidir. Pestisit ve herbisitlere karşı dayanıklı, yüksek besin kalitesine sahip, meyvelerde olgunlaşma zamanının değiştirilmesi, raf ve depolama ömrünün uzatılması ve aromanın artırılması gibi konular, üzerinde çalışılan başlıca konulardır. Bu anlamda, Türkiye'nin tıbbi ve aromatik bitki çeşitliliği bakımından yüksek bir potansiyele sahip olması, in vitro yöntemlerle çoğaltım ve kültüre alma, bu potansiyelin değerlendirilmesi bakımından oldukça önemlidir. Ancak bu yöntemlerin yeterince kullanılmaması, doğadan klasik usullerle ve tahribata neden olacak kadar bilinçsiz bir şekilde tıbbi ve aromatik özelliğe sahip bitkilerin toplanması, geleceğimiz için büyük bir kaygı yaratmaktadır. Bitkilerin bilinçsiz bir şekilde toplanması ekolojinin tahribatına ve bazı türlerin yok olmasına sebep olmaktadır. Ülkemizde hem çeşitlilik hem de miktar bakımından oldukça yoğun bir şekilde bulunan tıbbi aromatik bitkiler en kısa zamanda kültüre alınarak koruma altına alınmalıdır. Bu korumanın kapsamı yok olma tehlikesi altında bulunan ve bulunmayan aynı zamanda ticari olarak kıymetli olan tüm türler için mümkün mertebe geniş tutulmalıdır. In vitro koşullar altındaki üretimde istatistiksel anlamda bir standartın sağlanması, optimizasyonun gerçekleştirilmesi ile mümkün olacak ve başarı seviyesini belirlemede yardımcı olacaktır. Tıbbi ve aromatik bitkilerin kültüre alınmasında ve çoğaltılmasında in vitro tekniklerin araştırmacı ve üreticiye sunduğu imkanlar, günümüze kadar bu konuda yapılmış olan çalışmaların büyük bir kısmının toparlandığı bu çalışmadan kolaylıkla anlaşılmaktadır.

Sonuç olarak, sürdürülebilir ormancllık yaklaşımı çerçevesinde odun hammaddesi, yan ürün ve rekreasyonel amaçlı ormanların kullanımı oldukça önemlidir. Türkiye'de tıbbi ve aromatik bitkilerinin sürdürülebilir bir şekilde yönetimi, biyoteknoloji bilimi sayesinde ve çağın gerisinde kalmadan teknik bakımdan ve teknoloji bakımından gelişerek, bu alandaki sorunlara karşı yeni çözüm yolları bularak, donanımlı personel yetiştirerek ve tabi ki gerekli alt yapıyı hazırlayarak mümkündür. Bu anlamda planlanmış olan yeni üretim, yoğun ve klonal çoğaltım ile birlikte ıslah çalışmaları, yer ve zamanın verimli kullanılması, fizyolojik ve biyolojik sorunların çözümünde in vitro çoğaltım tekniklerinden yararlanılması, flora çeşitliliği bakımından eşsiz orman ve meralarımız için gerçek bir fırsattır.

\section{Kaynaklar}

Aawad, Z., Khateeb, J., \& Al-Ekbal, H. (2006). Using tissue culture technique for the production of cardiac glycosides from roots of Digitalis lamarckii Ivan plantlets (var excelsior mixed). Iraqi Journal of Pharmaceutical Science, 15(1), 92-98.

Abbasi, B.H., Khan, M.A., Mahmood, T., Mushtaq, A., Chaudhary, M.F., \& Khan, M.A. (2010). Shoot regeneration and free-radical scavenging activity in Silybum marianum L. Plant Cell, Tissue and Organ Culture, 101(3), 371-376.

Acar, S.Y., İşkil, R., \& Bürün, B. (2017). Safran (Crocus sativus L.) bitkisinde biyoteknolojik çalışmalar. Ĭgdır Üniversitesi Fen Bilimleri Enstitüsü Dergisi, 7(2), 259-269.

Akman, Y., \& Ketenoğlu, O. (1992). Vejetasyon Ekolojisi ve Araştırma Metodları. Ankara, Turkey, Ankara Üniversitesi Döner Sermaye İşletmesi Yayınları, $341 \mathrm{pp}$.

Arıcı, Ş.E., Şan, B., \& Kazaz, S. (2017). Yağ gülü (Rosa damascena Mill)'in in vitro koşullarda klonal çoğaltımı. Ordu Üniversitesi Bilim ve Teknoloji Dergisi, 7(2), 239-252.

Arslan, N., Baydar, H., Kızıl, S., Karık, Ü., Şekeroğlu, N., \& Gümüşcü, A. (2015). Türkiye Ziraat Mühendisliği 8. Teknik Kongresi (pp. 483-507) Ankara, Turkey, 600pp.

Arslan, N., Javani, M., \& Taher, M. (2016). Tıbbi bitkilerin yetiştiriciliğinde iyi tarım uygulamaları. Türkiye Tohumcular Birliği Dergisi, 16(1), 32-38.

Ayabe, M., \& Sumi, S. (2001). A novel and efficient tissue culture method"stem-disc dome culture"- for producing virüs free garlic (Allium sativum L.). Plant Growth Regulators, 20, 503-507.-30.

Babaoğlu, M., \& Özcan, S. (2001). Protoplast kültürü ve somatik melezleme. In M. Babaoğlu, E. Gürel \& S. Özcan (Eds.) Bitki Biyoteknolojisi I (pp. 89136). Konya, Turkey, $374 \mathrm{pp}$.

Başalma, D., Uranbey, S., Mirici, S., \& Özer, K. (2008). TDZ x IBA induced shoot regeneration from cotyledonary leaves and in vitro multiplication in safflower (Carthamus tinctorius L.). African Journal of Biotechnology, 7(8), 960-966.

Bayraktar, K.Ö.V., Öztürk, G., \& Arslan, D. (2017). Türkiye'de bazı tıbbi ve aromatik bitkilerin üretimi ve pazarlamasındaki gelişmelerin değerlendirilmesi. Tarla Bitkileri Merkez Araştırma Enstitüsü Dergisi, 26, 216-229.

Cardoza, V. (2008). Tissue Culture: The manipulation of plant development. In C.N., Stewart (Ed.), Plant Biotechnology and Genetics: Principles, Techniques, and Applications (pp. 113-134). New York, USA, 413 pp.

Carimi, F., Tortorici, M.C., Pasquale, F., \& Crescimanno, F.G. (1998). Somatic embryogenesis and plant regeneration from undeveloped ovules and stigma/style explants of sweet orange navel group [Citrus sinensis (L.) Osb.]. Plant Cell, Tissue and Organ Culture, 54, 183-189.

Chalak, L., \& Elbitar, A. (2006). Micropropagation of Capparis spinosa L. subsp. Rubestris Sibth. \& Sm. by nodal cuttings. Indian Journal of Biotechnology, 5(4), 555-558.

Chawla, H.S. (2002). Introduction to plant biotechnology. Boca Raton, USA, Science Publishers, $760 \mathrm{pp}$.

Chupeau, Y. Caboche, M., \& Henry, Y. (1998). The very first androgenetic plants. In Y. Chupeau, M. Caboche, \& Y. Henry (Eds.), Androgenesis and Haploid Plants (pp.1-7). Paris, France, Springer, 122 pp.

Çağlar, G., Aras, V., \& Bayram, A. (2004). Kurutmalık kırmızıbiberlerde androgenesis yoluyla in vitro haploid embriyo uyartımı. Akdeniz Üniversitesi Ziraat Fakültesi Dergisi, 17(1), 87-94.

Çetin, E.S., Kazaz, S., \& Göktürk, B.N. (2007). Farklı besin ortamlarının karanfil (Dianthus caryophyllus L.) sürgün ucu kültürü üzerine etkileri. Batı Akdeniz Tarımsal Araştırma Enstitüsü Dergisi, 24(2), 1-8. 
Daneshvar Royandazag, S. (2005). Papaver Bracteatum Lindl. Ve Papaver Pseudo-Orientale (Fedde) Medw.' De Adventif Sürgün Rejenerasyonu (Master Thesis). Ankara Üniversitesi, Ankara, Turkey.

Dilmen, R., \& Göktürk, B.N. (2016). Yağ gülü (Rosa damascena Mill.)'nde doku kültürü uygulamaları. Süleyman Demirel Üniversitesi Ziraat Fakültesi Dergisi, 11(2), 134-141.

Ebrahimie, E., Naghavi, M.R., Hosseinzadeh, A., Behamta, M.R., Manijeh, M., Sarrafi, D.A., \& Spangenberg, G. (2007). Induction and comparison of different in vitro morphogenesis path ways using embryo of cumin (Cuminum cyminum L.) as a model material. Plant Cell Tissue and Organ Culture, 90, 293-311.

Ellialtığlu, Ş., Sarı, N., \& Abak, K. (2000). Haploid bitki üretimi. In M. Babaoğlu, E. Gürel, \& S. Özcan (Eds.), Bitki Biyoteknolojisi I (pp.137-189). Konya, Turkey, Selçuk Üniversitesi Vakfı Yayınları, 374 pp.

Fang, J., Wetten, A., \& Hadley, P. (2004). Cryopreservation of cocoa (Theobroma cacao L.) somatic embryos for long term germplasm storage. Plant Science, 166(3), 669-675.

Faydaoğlu, E., \& Sürücüoğlu, M.S. (2011). Geçmisten günümüze tıbbi ve aromatik bitkilerin kullanılması ve ekonomik önemi. Kastamonu Üniversitesi Orman Fakültesi Dergisi, 11(1), 52-67.

Genç, L., \& Kaçar, O. (2012). Tıbbi ve aromatik bitkilerin tarım ve hayvancılık alanlarında kullanımı. In A. Kınay, \& B. Özyılmaz (Eds). Birinci Tıbbi aromatik bitkiler sempozyumu Bildirileri Kitabı (pp 7-28). Tokat, Turkey, Gaziosmanpaşa Üniversitesi Press., 537 pp.

Georgiev, V., Ivanov, I., Berkov, S., Ilieva, M., Georgiev, M., Gocheva, T., \& Pavlov, A. (2012). Galanthamine production by Leucojum aestivum L. shoots culture in a modified bubble column bioreactor with internal sections. English Life Sciences, 12(5), 534-543.

Gopi, C., \& Ponmurugan, P. (2006). Somatic embryogenesis and plant regeneration from leaf callus of Ocimum basilicum L. Journal of Biotechnology, 126(2), 260-264.

Güven, A., \& Gürsul, I. (2014). Bitki doku kültürlerinde sekonder metabolit sentezi. Gida Dergisi, 39(5), 299-306.

Harshan, M.L., \& Nag, T.N. (1984). Antimicrobial principles from in vitro tissue culture of Peganum harmala L. Journal of Natural Production, 47(2), 365-367.

Hartman, H.T., \& Kester, D.E. (1975). Plant propagation principles and practices. New Jersey, USA, Pearson, 662 pp.

Karaoğlu, C. (2004). Göl soğanı (Leucojum aestivum L.) 'nın in vitro koşullarında hızlı çoğaltımı (Master Thesis) Ankara Üniversitesi, Ankara, Turkey.

Koçak, M., İzgüp, T., Sevindik, B., Tütüncü, M., Curuk, P., Simşek, Ö., Kaçar, A.Y., Jaime, A., Silvac, T., \& Yalçın, Y. (2014). Somatic embriyogenesis of Turkish Cyclamen persicum Mill. Scientia Horticulturae, 172(9), 26-33.

Ljubinka, U., Snezana, B., Radmila, V., \& Mirjana, N.K. (1987). Induction of somatic embryogenesis and embryo development in Rumex acetosella $\mathrm{L}$. Plant Cell, Tissue and Organ Culture, 11(2), 133-139.

M.W. Fowler, G.S. Warren, \& M. Moo-Young (Eds.), Plant Biotechnology: Comprehensive Biotechnology (pp.99-127). New York, USA, pp.81.

Mansuroğlu, S., \& Gürel, M. (2001). Mikroçoğaltım. In M. Babaoğlu, E. Gürel, \& S. Özcan (Eds.) Bitki biyoteknolojisi I (pp.262-281). Konya, Turkey, $374 \mathrm{pp}$.

Meriç, S., Tuman, C. B., Ayan, A., \& Atak, Ç. (2019). Optimization of tissue culture media-inducing essential oil production of levander (Lavandula angustifolia Mill.). Physiology and Molecular Biology of Plants, 25(1), 85-99.

Mert, A., \& Dağıstan, E. (2016). Tibbi ve aromatik bitkilerin ekonomik önemi. Süleyman Demirel Üniversitesi Ziraat Fakültesi Tarmm Ekonomisi Bölümü Yayınları, 1, 1-8.

Moallem, S., Behbahani, M., Mousavi, E., \& Karimi, N. (2012). Direct regeneration of Rosa canina L. through tissue culture. Annual Edition Trakia Journal of Science, 10(3), 23-25.

Murashige, T., \& Skoog, F. (1962). A revised medium for rapid growth and bioassays with tobacco tissue cultures. Physiologie Plant, 15,473-497.

Ochatt, S.J., \& Power, J.B. (1992). Plant regeneration from cultured protoplasts of higher. In M.W. Fowler, G.S. Warren, \& M. Moo-Young (Eds.), Plant Biotechnology: Comprehensive Biotechnology (pp.99-127). New York, USA, Oxford Pergamon Press., 367 pp.

Ovecka, M., Bobak, M., Blehova, A., \& Kristin, J. (1997). Papaver somniferum regeneration by somatic embryogenesis and shoot organogenesis. Biologia Plant Journal, 40(3), 321-328.

Özcan, S., Babaoğlu, M. \& Sancak, C. (2001). Somatik embriyogenesis In M. Babaoğlu, E. Gürel, \& S. Özcan (Eds.), Bitki Biyoteknolojisi I (pp.71-88). Konya, Turkey, Selçuk Üniversitesi Vakfı Yayınları, 374 pp.

Özdemir, F.A., Uğur, M., Yıldırım, B., \& Kahrizb, M.P. (2015). Mentha spicata L. subsp. spicata L. ve M. spicata hipokotilinden in vitro çoklu sürgün rejenerasyonu. Anadolu Tarım Bilimleri Dergisi, 30(2), 126-129.
Özüdoğru, E.A., Kaya, E., Kırdok, E., İşsever, A., \& Öztürk, S. (2011). In vitro propagation from young and mature explants of Thyme (Thymus vulgaris and T. longicaulis) resulting in genetically stable shoots. In vitro Cellular and Developmental Biology-Plant, 47(2), 309-320.

Palmer, C.E., \& Keller, W.A. (1997). Pollen embryos. In K.R. Shivanna, \& V.K Sawhney (Eds.), Pollen Biotechnology for Crop Production and Improvement (pp.392-422). Cambridge, UK, Cambridge University Press., 500 pp.

Panizza, M., \& Tognoni, F. (1992). Micropropagation of lavander (Lavandula officinalis Chaix x Lavandula latifolia Villars cv. Grosso). In Y.P.S. Bajaj (Eds.), Biotechnology in Agriculture and Forestry Journal (pp.295-305) Pisa, Italy, Springer, $593 \mathrm{pp}$.

Primard, C., Vedel, F., Mathieu, C., Pelletier, G., \& Chavre, A.M. (1988). Interspecific somatic hybridization between Brassica napus and Brassica hirta (Sinapis alba L.). Theorical Apple Genetic, 75, 546-552.

Ren, J.W., Rei, L.Y., \& Li, X.L. (2017). Tissue culture of callus and establishment of regeneration system of Tussilago farfara petiole. Europepmc.org. 42(20), 3895-3900.

Rodriguez, R., Rey, M., Cuozzo, L., \& Ancora, G. (1990). In vitro propagation of Caper (Capparis spinosa L.). In vitro Cellular \& Developmental Biology, 26, 531-536.

Saini, R. \& Jaiwal, P.K. (2000). In vitro multipication of Peganum harmala-an important medicinal plant. Indian Journal of Experimental Biology, 38(5), 499-503.

Saker, M., Gengaihi, S.E., Kamel, A., \& Farid, M. (2010). Influence of differentiation state, salt stress and methyl jasmonate on in vitro production of cucurbitacins from tissue cultures of Ecballium elaterium and Cucumis prophetarum endemic to Egypt. Medicinal and Aromatic Plant Science and Biotechnology, 4(1), 28-32.

Soliman, H.I., \& Hegazi, G.A.M. (2013). In vitro clonal propagation and molecular characterization of jujube (Ziziphus jujuba Mill.). Life Science Journal, 10(2)-573-582.

Stephen, R., \& Jayabalan, N. (1998). In vitro flowering and seed setting formation of coriander (Coriandrum sativum L.). Current Science Association Journal, 74(3), 195-197.

Tanrıseven, A. (2013). Tibbi aromatik bitkiler biyo sağlık ve ekonomi. Bat Akdeniz Tarımsal Araştırma Enstitüsü Dergisi, 3, 44-58.

Topçu, Ş., \& Çölgeçen, H. (2015). Bitki sekonder metabolitlerinin biyoreaktörlerde üretilmesi. Türk Bilimsel Derlemeler Dergisi, 8(2), 9-29.

Türker, A., \& Hatipoğlu, R. (2018). Dağ kekiği (Origanum syriacum L. var. bevanii (Holmes) Ietswaart)'nin mikroçoğaltımı. Ormancılık Araştırma Dergisi, 5(2), 97-111.

Uçar, E., \& Turgut, K. (2009). Bazı dağ çayı (Sideritis) türlerinin in vitro çoğaltımı. Akdeniz Üniversitesi Ziraat Fakültesi Dergisi, 22(1), 51-57.

Ünaldı, E.Ü. (2007). A plant exposed to danger: saffron (Crocus sativus L.). Firat Üniversitesi Sosyal Bilimler Dergisi 17(2), 53-69.

Vandermoortele, J.L., Billard, J.P., Boucaud, J., \& Gaspar, T.H. (1996). Micropropagation of parsley through axillary shoot proliferation. Plant Cell, Tissue and Organ Culture, 44(1), 25-30.

Wang, L., Wang, G., Hong, N., Tang, R., Deng, X., \& Zhang, H. (2006). Effect of thermotherapy on the elimination of Apple stem grooving virus and apple chlorotic leaf spot virüs for in vitro-cultured pear shoot tips. Horticultural Sciences, 41(3), 729-732.

Whipkey, A., James, E., \& Janick, S.J. (1988). In vivo and in vitro lipid accumulation in Borago officinalis L. JAOCS, 65(6), 979-985.

Yücesan, B.B., Eker, İ., Lazzarini, L.E.S., Aslam, N., Mohammed, A., Pinto, J.E.B.P., Kreis, W., \& Gürel, E. (2018). Shoot-tip cultivation and cardenolide content analysis of natural populations of Digitalis lanata Ehrh. subsp. lanata (wooly foxglove) in the Thrace region. International Journal of Agriculture and Wildlife Science, 4(1), 55-62. 